\title{
Ameliorating the effects of Adalimumab on rabbits with experimental cerebral vasospasm after subarachnoid hemorrhage
}

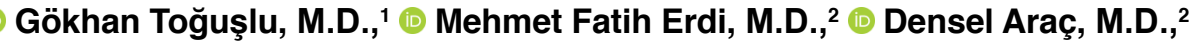 \\ Fatih Keskin, M.D., ${ }^{2}$ (D) Ibrahim Kılınç, M.D., ${ }^{3}$ (1) Gökhan Cüce, M.D. ${ }^{4}$
}

\author{
${ }^{1}$ Department of Neurosurgery, Kadirli State Hospital, Osmaniye-Turkey \\ ${ }^{2}$ Department of Neurosurgery, Necmettin Erbakan University Meram Faculty of Medicine, Konya-Turkey \\ ${ }^{3}$ Department of Biochemistry, Necmettin Erbakan University Meram Faculty of Medicine, Konya-Turkey \\ ${ }^{4}$ Department of Histology and Embryology, Necmettin Erbakan University Meram Faculty of Medicine, Konya-Turkey
}

\begin{abstract}
BACKGROUND: Adalimumab (ADA), which is a new-generation recombinant human monoclonal antibody for tumor necrosis factor $\alpha$ (TNF $\alpha$ ), has strong anti-inflammatory effects. The role of enhanced inflammation is well established for the development and progression of cerebral vasospasm. Investigated in the present study is the probable ameliorating and neuroprotective effects of ADA in rabbits using a cerebral vasospasm model with biochemical and histopathological methods.
\end{abstract}

METHODS: Thirty male New-Zealand white rabbits were randomly divided into control, subarachnoid hemorrhage (SAH) only and SAH plus ADA treatment groups. SAH was established as a single cisterna magna autologous arterial blood injection. ADA treatment was started just after intracisternal blood injection and continued for 72 hours once a day. The animals were sacrificed 72 hours after the induction of $\mathrm{SAH}$, serum and brainstem tissue obtained for investigations.

RESULTS: Brainstem tissue and plasma levels of tumor necrosis factor-alpha and Interleukin-I $\beta$, brainstem tissue Matrix metalloproteinase-9 levels increased after SAH and partly decreased after treatment. Plasma levels of brain-derived neurotrophic factor decreased after SAH and partly restored after treatment. ADA treatment significantly increased the mean cross-sectional area of the vasospastic basilar arteries, reduced the basilar artery wall thickness and also ameliorates enhanced endothelial apoptosis.

CONCLUSION: Findings obtained in this study suggest that ADA is an effective neuroprotective agent for ameliorating cerebral vasospasm in experimental rabbit vasospasm.

Keywords: Adalimumab; cerebral vasospasm; cytokine; inflammation; neuroprotection; rabbit; subarachnoid hemorrhage.

\section{INTRODUCTION}

Cerebral vasospasm is an important complication of subarachnoid hemorhage (SAH), which leads to enhanced mortality and morbidity. Despite intensive studies, its multifactorial pathogenesis is not elucidated yet. ${ }^{\left[{ }^{I}\right]}$ Enhanced inflammation has been postulated as an important cause of vasospasm in both experimental[ ${ }^{[2]}$ and clinical ${ }^{[3]}$ studies. Increased levels of adhesion molecules have been found in both cerebrospinal fluid (CSF) and serum of SAH patients, which may lead to the accumulation of leukocytes in inflamed tissue. ${ }^{[4]}$ Enhanced cytokines $^{[3]}$ and activated complement system play important roles in $^{[4]}$ initiation of the multifaceted cascade of vasospasm after SAH. Tumor necrosis factor-alpha (TNF $\alpha$ ) is an important proinflammatory cytokine that regulates systemic inflammation. Adalimumab (ADA) is a recombinant human IgGI monoclonal antibody for TNF $\alpha$, which binds TNF $\alpha$ by antigen-antibody interaction and inhibits its binding to its re-

Cite this article as: Toğuşlu G, Erdi MF, Araç D, Keskin F, Kılınç İ, Cüce G. Ameliorating the effects of Adalimumab on rabbits with experimental cerebral vasospasm after subarachnoid hemorrhage. Ulus Travma Acil Cerrahi Derg 2020;26:847-852.

Address for correspondence: Densel Araç, M.D.

Necmmetin Erbakan Üniversitesi Meram Tıp Fakültesi, Nöroşirurji Anabilim Dalı, Konya, Turkey

Tel: +90 332 - 2236150 E-mail: denselarac@hotmail.com

Ulus Travma Acil Cerrahi Derg 2020;26(6):847-852 DOI: 10.14744/tjtes.2019.52504 Submitted: 03.09.2019 Accepted: 31.12 .2019 Online: 21.10 .2020

Copyright 2020 Turkish Association of Trauma and Emergency Surgery 
ceptor. ${ }^{[5]}$ In this study, we aimed to investigate the effects of ADA on experimentally induced cerebral vasospasm by its strong anti-inflammatory properties.

\section{MATERIALS AND METHODS}

The experimental protocol was approved by the local Animal Ethics Committee (2016-042). All animals breathed spontaneously throughout the procedures. Arterial blood samples were taken from each animal from the catheterized ear arteries for blood gas analysis during the procedures. Heart rate and systemic blood pressure were measured with the use of an ear artery catheter. Core body temperature was monitored rectally and maintained at $37^{\circ} \pm 0.5^{\circ} \mathrm{C}$ with a heater. Mean physiological parameter values were not statistically significant between the groups $(p>0.05)$.

Cerebral vasospasm was obtained by a single fresh nonheparininized autologous arterial blood injection to the cisterna magna of the rabbit. ${ }^{[1]}$ Briefly, the head of the rabbit was extended in the prone position. With the use of aseptic techniques, a midline nuchal incision was made, the atlanto-occipital membrane was exposed and cisterna magna was punctured by a 25 gauge needle. $1.0 \mathrm{~mL} / \mathrm{kg}$ of cerebrospinal fluid was withdrawn and an equal volume of blood injected into the cisterna magna within two minutes. Layers closed in anatomical planes after the needle were withdrawn. The animals were then placed in a head-down position for 15 minutes to facilitate blood settling around the basilar artery. After the recovery from anesthesia, and confirmation of vital signs, rabbits were left to their cages.

\section{Groups}

Thirty male New-Zealand white rabbits weighing 2000-3000 $g$ were assigned randomly into three groups as follows: group I: control group $(n=10)$, group 2 : SAH alone group $(n=10)$, group 3: SAH + ADA treatment group.

Group I (control group, $\mathrm{n}=10$ ) was a sham surgery group in which SAH was not induced. In this group, after induction of anesthesia, the atlanto-occipital membrane was exposed as described above and the cisterna magna was aseptically punctured by a 25 -gauge needle, and $1 \mathrm{~mL} / \mathrm{kg}$ of physiological saline $(0.9 \% \mathrm{NaCl})$ was slowly injected into the cisterna magna after removal of the same amount of CSF.

In group II (SAH only group, $n=10)$, the $\mathrm{SAH}$ protocol was used to induce cerebral vasospasm as described above.

In group III (SAH + ADA group, $n=10)$, cerebral vasospasm was induced by $\mathrm{SAH}$, as described above, and the rabbits received ADA (Humira, Abbott Laboratories, North Chicago, IL, USA) treatment. ADA $5 \mathrm{mg} / \mathrm{kg} /$ day was given intraperitoneally. The treatment was started just after intracisternal blood injection and continued for 72 hours once a day. This dosage and treatment regimen was decided according to the literature. ${ }^{[6]}$ The animals tolerated this dosage well without any important side effects.

The animals were sacrificed under general anesthesia 72 hours after the induction of SAH. Before sacrification, 2cc fresh arterial blood was obtained from the ear artery of each rabbit. All rabbits were transcardiac perfused, as described. The thorax was opened and a cannula was placed in the aorta using the left ventricle. The right atrial appendage was opened, and the descending thoracic aorta clamped. The vascular system was perfused with $300 \mathrm{ml}$ of physiological saline under a pressure of $120 \mathrm{~cm} \mathrm{H}_{2} \mathrm{O}$.

After perfusion, the brain and brainstem were removed, and each brainstem cut coronally into two pieces as follows: the anterior part that contains basilar artery histopathological investigations and the dorsal part that contains brainstem tissue for biochemical investigations.

\section{Biochemical Procedures}

Brainstem tissues (dorsal part) of the rabbits were extracted after decapitation and rinsed with ice-cold PBS (phosphate-buffered saline) containing heparin and blood and clot remnants were removed. Subsequently, tissues were blotted on filter paper and stored in Eppendorf tubes at $-80^{\circ} \mathrm{C}$ until biochemical analysis. Brain tissue samples were weighed and homogenized. Homogenates were centrifuged at $+4 \mathrm{C}^{\circ}$ and $10.000 \mathrm{~g}$ for 10 minutes.

Serum concentrations of the brain-derived neurotrophic factor (BDNF), TNF $\alpha$, interleukin I beta (IL-I $\beta$ ) and brainstem tissue concentrations of the matrix metalloproteinase (MMP9), TNF $\alpha$ and IL-I $\beta$ were measured using the iMark ${ }^{\text {TM }}$ Microplate Absorbance Reader, (Bio-rad Laboratories, CA, USA) using ELISA (enzyme-linked immunosorbent assay) analysis with rabbit BDNF, TNF $\alpha$ and IL-I $\beta$ kits (Sunred Biological Technology Co., Ltd, Shanghai, China). Tissue protein levels were measured using the Thermo Scientific Pierce ${ }^{T M}$ BCA Protein Assay Kit (Thermo Fisher Scientific, IL, USA).

\section{Histopathological Procedures}

In total, five artery sections were analysed per animal. The morphometric and immunohistological analyses were carried out in a blind fashion by one pathologist. Morphometric measurements on all five segments of the basilar artery were performed using an image analysis system (BAB image analysing systems, Ankara, Turkey). The luminal area was calculated from the perimeter of the luminal border and the area contained within the boundaries of the internal elastic lamina was neglected. The luminal area for each basilar artery was obtained by averaging these measurements. The mean \pm standard error of the mean (SEM) value obtained from each artery was used as the final value for a particular vessel. 
For labeling apoptotic cells in samples by modifying DNA fragments utilizing terminal deoxynucleotidyl transferase for detection of apoptotic cells by specific staining the ApopTag ${ }^{\circledR}$ Plus Peroxidase In Situ Apoptosis Detection Kit (CHEMICON ${ }^{\circledR}$ International, Inc.) was used as described in user manual. An apoptotic index was calculated as the number of the immunoreactive nuclei per total number of endothelial cells and the result was expressed as a percentage.

\section{Statistical Analysis}

The SPSS (version 2 I.0, IBM SPSS Statistics, IL, USA) program was used to evaluate the findings of this study. The differences among groups were tested using the Kruskal-Wallis test. The Post-Hoc Bonferroni and Mann-Whitney $U$ tests were used for the correction of groups in which diference were significant. A P-value less then 0.05 was accepted as significant $(p<0.05)$.

\section{RESULTS}

All thirty animals survived to complete this study. The animals in the SAH only group was hypoactive and lethargic. Rabbits in the control group and ADA treated groups were as active as they were before.

\section{Biochemical Results}

Tissue levels of TNF $\alpha$, IL-I $\beta$ and MMP-9 elevated in the group 2 and they partly decreased in the group III. Plasma levels of TNF $\alpha$ and IL-I $\beta$ also elevated in group II and partly decreased in the group III. In contrast, plasma levels of BDNF were higher in the group I, significantly reduced in group II and partly restored in group III. Findings are summarized in Table I.

\section{Histopathological Results}

The mean cross-sectional area of the basilar artery significantly reduced after SAH when compared with group I. ADA treatment statistically significantly increased the mean cross-sectional area of the basilar artery when compared with group II. SAH-induced cerebral vasospasm significantly increased the wall thickness of the basilar artery, and ADA treatment statistically significantly reduced this increment. $\mathrm{SAH}$ statistically significantly increased the mean percentage of endothelial apoptotic cells when compared with group I. ADA treatment leads to a statistically significant reduction in the mean percentage of apoptotic endothelial cells when compared with group II. Morphometric and immunohistological results were presented in Table 2 and Figure $I$ and Figure 2.

\section{DISCUSSION}

Cerebral vasospasm is an important complication of SAH, which leads to enhanced mortality and morbidity. ${ }^{[7]}$ Despite extensive clinical and experimental studies, exact treatment of vasospasm is obscure. Multifactorial ethiopathogenesis of the vasospasm include lipid peroxide formation, an instability among endothelium-derived vasoconstrictor and vasodilator substances, nitric oxide toxicity, arachidonic acid metabolites, inflammatory cascades, a deterioration of neuronal mechanisms that regulate vascular tone, endothelial proliferation, and apoptosis. ${ }^{[8]}$

SAH triggers a systemic inflammatory cascade, which increases the level of circulating leukocytes and adhesion molecules, which cause accumulation of immunoreactive cells. ${ }^{[4]}$ Progressing inflammatory response in the subarachnoid space is mediated by the release of various cytokines. Fassbender et

Table I. Brainstem tissue and plasma levels of the biochemical parameters

\begin{tabular}{lccccrc}
\hline & $\begin{array}{c}\text { Tissue TNF } \alpha \\
\text { (pg/mg protein) }\end{array}$ & $\begin{array}{c}\text { Tissue IL-I } \beta \\
(\mathbf{p g} / \mathbf{m g} \text { protein) }\end{array}$ & $\begin{array}{c}\text { Tissue MMP9 } \\
(\mathbf{n g} / \mathbf{m g} \text { protein) }\end{array}$ & $\begin{array}{c}\text { Plasma BDNF } \\
(\mathbf{p g} / \mathbf{m L})\end{array}$ & $\begin{array}{c}\text { Plasma TNF } \alpha \\
(\mathbf{p g} / \mathbf{m L})\end{array}$ & $\begin{array}{c}\text { Plasma IL-I } \beta \\
(\mathbf{p g} / \mathbf{m L})\end{array}$ \\
\hline Group I & $1.16 \pm 0.16$ & $1.90 \pm 0.16$ & $0.61 \pm 0.06$ & $661.60 \pm 56.68$ & $18.26 \pm 7.36$ & $25.64 \pm 1.08$ \\
Group II & $3.39 \pm 1.52$ & $5.71 \pm 3.72$ & $1.29 \pm 0.20$ & $293.80 \pm 29.32$ & $44.86 \pm 2.58$ & $55.00 \pm 3.92$ \\
Group III & $1.40 \pm 0.14^{*}$ & $2.82 \pm 0.37^{*}$ & $0.85 \pm 0.09^{*}$ & $435.30 \pm 33.27^{*}$ & $23.23 \pm 1.29^{*}$ & $50.05 \pm 2.21^{*}$ \\
\hline
\end{tabular}

*Statistically significantly difference when compared with group II $(p<0.05)$. The presented values were given as the mean \pm SEM.

Table 2. Morphometric and immunohistological results

\begin{tabular}{lccc}
\hline & Cross-sectional area $\left(\boldsymbol{\mu m}^{2}\right)$ & Wall thickness $(\boldsymbol{\mu m})$ & Apoptotic Index (\%) \\
\hline Group I & $89202 \pm 3609$ & $41.67 \pm 1.57$ & $3.3 \pm 0.47$ \\
Group II & $53231 \pm 1921$ & $65.42 \pm 0.95$ & $36.4 \pm 2.07$ \\
Group III & $67687 \pm 1800^{*}$ & $51.07 \pm 1.23^{*}$ & $16.9 \pm 1.36^{*}$ \\
\hline
\end{tabular}

*Statistically significantly difference when compared with group II $(p<0.05)$. The presented values were given as the mean \pm SEM. 

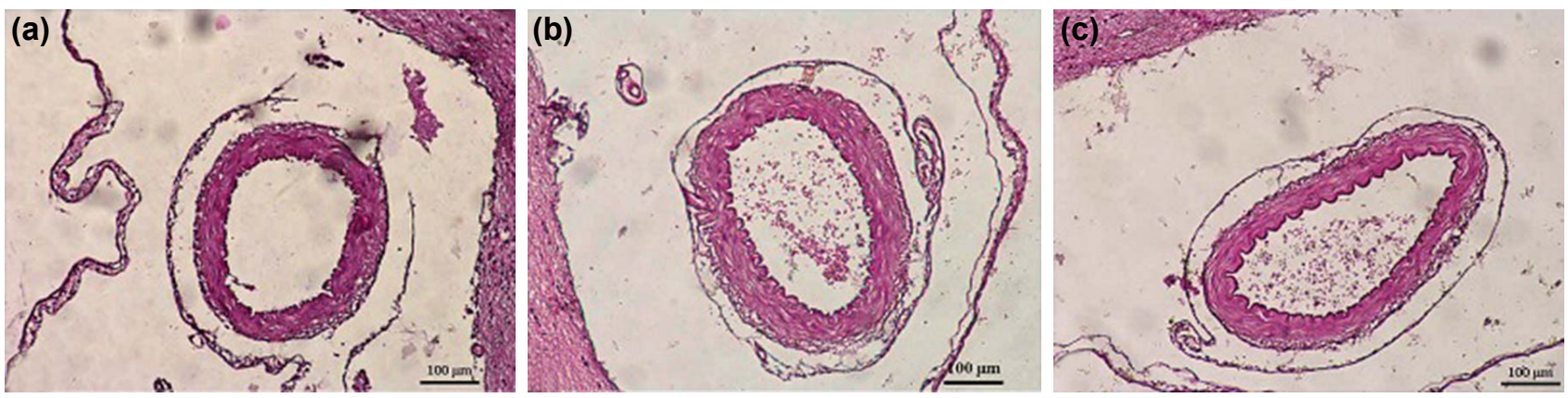

Figure 1. Representative hematoxylin-eosin (H\&E)-stained basiller artery sections. (a) Group I, (a) Group II, (a) Group III (Bar=100 $\mu$ m).
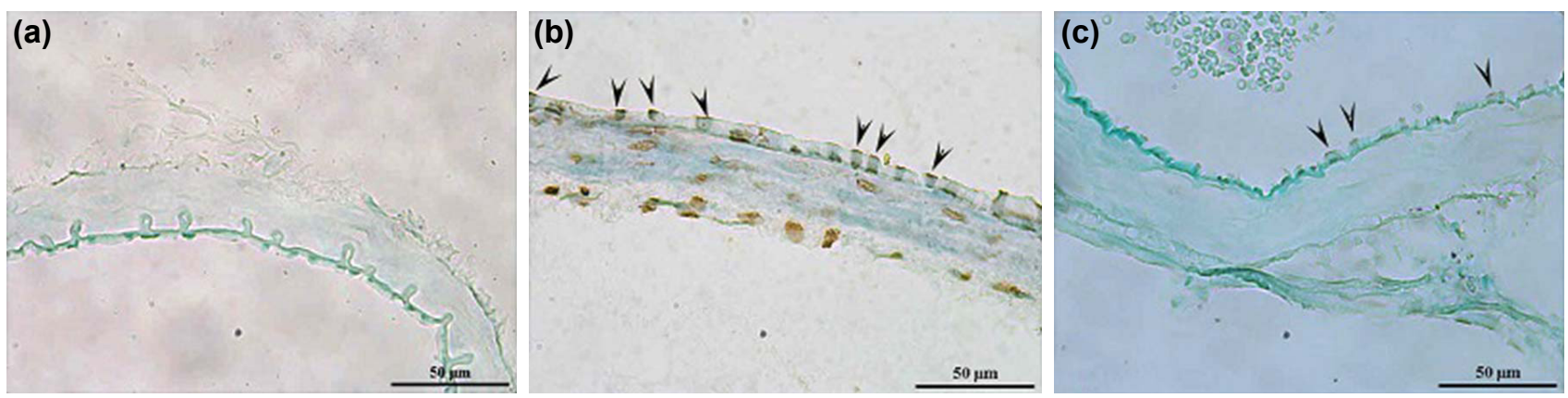

Figure 2. (a) Representative basiller artery sections stained in the TUNEL assay. (a) Group I, (b) Group II, (c) Group III. The black arrows indicate immunoreactive apoptotic endothelial cells (Bar=50 $\mu \mathrm{m})$.

al..$^{[3]}$ and Takizawa et al. ${ }^{\left[{ }^{[9]}\right.}$ reported an association between cytokines (powerful mediators and regulators of immune responses) in the CSF of patients with cerebral vasospasm after SAH. Takizawa et al. ${ }^{[9]}$ concluded that regulation of cytokines might become a method to prevent complications following $\mathrm{SAH}$. Bowman et al. ${ }^{[10,11]}$ reported some therapeutic effects of cytokine-mediated treatments in the management of experimental cerebral vasospasm. A few cytokines, including TNF $\alpha$, IL-I, IL-6, and IL-8, have been found to be upregulated in cerebral vasospasm. ${ }^{[2]}$ Among these cytokines, TNF $\alpha$ takes particular interest in the development and progression of some central nervous diseases, including multiple sclerosis, ${ }^{[13]}$ Alzheimer's disease ${ }^{[14]}$ and autoimmune encephalomyelitis. ${ }^{[15,16]}$

ADA is a human monoclonal TNF $\alpha$ antibody drug that blocks the effects of TNF $\alpha$. Adalimumab is used successfully for the treatment of disorders, such as Crohn's disease, ulcerative colitis, psoriasis, rheumatoid arthritis, psoriatic arthritis, ankylosing spondylitis. ${ }^{[5,17]}$ To our knowledge, to date, there is no study in the literature concerning the beneficial effects of ADA on cerebral vasospasm.

Inflammatory cytokines, TNF $\alpha$ and IL-I $\beta$, have been shown to play a role in the development and progression of cerebral vasospasm and ischemia response after cerebral hemorrhage by accelerating the inflammatory response cascade. ${ }^{[18-20]}$ In addition, TNF $\alpha$ and IL-I $\beta$ play important roles in the activation of the apoptotic process. ${ }^{[21,22]}$ Previous studies showed that the prevention of apoptosis ameliorates cerebral vasospasm. ${ }^{[8,23]}$ MMP-9 is a collagen-degrading enzyme altering blood-brain barrier. Both have similar deleterious effects on the ischemic brain. ${ }^{[2]}$ Recent clinical evidence verified the involvement of MMP-9 in the pathological process of hemorrhagic stroke and aggravation of the early brain injury and cerebral vasospasm after SAH. ${ }^{[25]}$ TNF $\alpha$ induces MMP-9 expression by some signaling pathways that contribute to enhanced inflammation. ${ }^{[26]}$ Inhibiting TNF $\alpha$ by ADA treatment ameliorates MMP-9 related joint inflammation in psoriasis patients. ${ }^{[27]}$ In the present study, ADA treatment after experimental SAH ameliorates the emerging cerebral vasospasm by decreasing brainstem tissue TNF $\alpha$, IL-I $\beta$, MMP-9 levels and plasma levels of TNF $\alpha$ and IL-I $\beta$.

BDNF have well-known neurotrophic actions and also maintains other neuroprotective effects, including anti-apoptosis, anti-oxidation, and suppression of autophagy. Various protective mechanisms of BDNF against mitochondrial dysfunction commonly associated with the pathogenesis of many chronic neurodegenerative disorders and the protective signaling pathways revealed by BDNF is under investigation for prevention from the progression of neurodegeneration. ${ }^{[28]}$ In our study, plasma levels of BDNF as a marker of neuroprotection were also restored in the ADA treatment group.

Cerebral vasospasm affects all layers of the arterial wall with morphologic changes observed in the adventitia, media and intima. Cellular proliferation of cells in the arterial wall and apoptosis of endothelial cells leading to impairment of endothelium-dependent vasorelaxation promotes exposure of vascular smooth muscle cells to spasmogens and enhances vasospasm. ${ }^{[8]}$ In this study, ADA treatment significantly in- 
creased the mean cross-sectional area of the vasospastic basilar arteries, reduced the basilar artery wall thickness and also ameliorates enhanced endothelial apoptosis.

\section{Conclusion}

The findings obtained in this study suggest that ADA caused significant changes in cytokine activity, with positive effects on the amelioration of cerebral vasospasm. Beneficial anti-inflammatory, anti-apoptotic, neuroprotective effects of ADA worth further investigation for the implement this treatment option into the clinical practice.

Ethics Committee Approval: The Necmettin Erbakan University KONÜDAM Experimental Medicine Application and Research Center Directorate granted approval for this study (date: 29.07.2016, number: 2016-042).

Peer-review: Internally peer-reviewed.

Authorship Contributions: Concept: M.F.E., G.T.; Design: M.F.E., G.T., D.A., F.K.; Supervision: M.F.E.; Resource: G.T.; Materials: G.T.; Data: G.T., M.F.E., F.K., I.K., G.C.; Analysis: G.T., M.F.E., F.K., I.K., G.C.; Literature search: M.F.E., D.A., F.K.; Writing: M.F.E., D.A.; Critical revision: M.F.E., F.K.

\section{Conflict of Interest: None declared.}

Financial Disclosure: The authors declared that this study has received no financial support.

\section{REFERENCES}

1. Erdi MF, Guney O, Kiyici A, Esen H. The effects of alpha lipoic acid on cerebral vasospasm following experimental subarachnoid hemorrhage in the rabbit. Turk Neurosurg 2011;21:527-33. [CrossRef]

2. Bavbek M, Polin R, Kwan AL, Arthur AS, Kassell NF, Lee KS. Monoclonal antibodies against ICAM-1 and CD18 attenuate cerebral vasospasm after experimental subarachnoid hemorrhage in rabbits. Stroke 1998;29:1930-6. [CrossRef]

3. Fassbender K, Hodapp B, Rossol S, Bertsch T, Schmeck J, Schütt S, et al. Inflammatory cytokines in subarachnoid haemorrhage: association with abnormal blood flow velocities in basal cerebral arteries. J Neurol Neurosurg Psychiatry 2001;70:534-7. [CrossRef]

4. Dumont AS, Dumont RJ, Chow MM, Lin CL, Calisaneller T, Ley KF, et al. Cerebral vasospasm after subarachnoid hemorrhage: putative role of inflammation. Neurosurgery 2003;53:123-35. [CrossRef]

5. Tsilimbaris M, Diakonis VF, Naoumidi I, Charisis S, Kritikos I, Chatzithanasis $\mathrm{G}$, et al. Evaluation of potential retinal toxicity of adalimumab (Humira). Graefes Arch Clin Exp Ophthalmol 2009;247:1119-25.

6. Polat E, Dağlığlu E, Menekşe G, Dike MS, Özdöl Ç, Türk CÇ, et al. Neuroprotective effects of adalimumab on rats with experimental peripheral nerve injury: An electron microscopic and biochemical study. Ulus Travma Acil Cerrahi Derg 2016;22:134-8. [CrossRef]

7. Bramlett HM, Dietrich WD. Pathophysiology of cerebral ischemia and brain trauma: similarities and differences. J Cereb Blood Flow Metab 2004;24:133-50. [CrossRef]

8. Kolias AG, Sen J, Belli A. Pathogenesis of cerebral vasospasm following aneurysmal subarachnoid hemorrhage: putative mechanisms and novel approaches. J Neurosci Res 2009;87:1-11. [CrossRef]

9. Takizawa T, Tada T, Kitazawa K, Tanaka Y, Hongo K, Kameko M, et al. Inflammatory cytokine cascade released by leukocytes in cerebrospinal fluid after subarachnoid hemorrhage. Neurol Res 2001;23:724-30.
10. Bowman G, Dixit S, Bonneau RH, Chinchilli VM, Cockroft KM. Neutralizing antibody against interleukin- 6 attenuates posthemorrhagic vasospasm in the rat femoral artery model. Neurosurgery 2004;54:719-26.

11. Bowman G, Bonneau RH, Chinchilli VM, Tracey KJ, Cockroft KM. A novel inhibitor of inflammatory cytokine production (CNI-1493) reduces rodent post-hemorrhagic vasospasm. Neurocrit Care 2006;5:222-9.

12. Siasios I, Kapsalaki EZ, Fountas KN. Cerebral vasospasm pharmacological treatment: an update. Neurol Res Int. 2013;2013:571328. [CrossRef]

13. Sharief MK, Hentges R. Association between tumor necrosis factor-alpha and disease progression in patients with multiple sclerosis. N Engl J Med 1991;325:467-72. [CrossRef]

14. Decourt B, Lahiri DK, Sabbagh MN. Targeting Tumor Necrosis Factor Alpha for Alzheimer's Disease. Curr Alzheimer Res 2017;14:412-25.

15. Rostami Mansoor S, Allameh A, Parsian H. An Apparent Correlation Between Central Nervous System and Kidney's Erythropoietin and TNF Alpha Expression at Peak Experimental Autoimmune Encephalomyelitis Disease. J Mol Neurosci 2018;65:246-54. [CrossRef]

16. Selmaj K, Raine CS, Cross AH. Anti-tumor necrosis factor therapy abrogates autoimmune demyelination. Ann Neurol 1991;30:694-700.

17. Celik H, Karatay M, Erdem Y, Yildirim AE, Sertbas I, Karatay E, et al. The Biochemical, Histopathological and Clinical Comparison of the Neuroprotective Effects of Subcutaneous Adalimumab and Intravenous Methylprednisolone in an Experimental Compressive Spinal Cord Trauma Model. Turk Neurosurg 2016;26:622-31. [CrossRef]

18. Silva Y, Leira R, Tejada J, Lainez JM, Castillo J, Dávalos A; Stroke Project, Cerebrovascular Diseases Group of the Spanish Neurological Society. Molecular signatures of vascular injury are associated with early growth of intracerebral hemorrhage. Stroke 2005;36:86-91. [CrossRef]

19. Achrol AS, Pawlikowska L, McCulloch CE, Poon KY, Ha C, ZaroffJG, et al; UCSF BAVM Study Project. Tumor necrosis factor-alpha-238G >A promoter polymorphism is associated with increased risk of new hemorrhage in the natural course of patients with brain arteriovenous malformations. Stroke 2006;37:231-4. [CrossRef]

20. Yang G, Shao GF. Elevated serum IL-11, TNF $\alpha$, and VEGF expressions contribute to the pathophysiology of hypertensive intracerebral hemorrhage (HICH). Neurol Sci 2016;37:1253-9. [CrossRef]

21. Van Antwerp DJ, Martin SJ, Kafri T, Green DR, Verma IM. Suppression of TNF-alpha-induced apoptosis by NF-kappaB. Science 1996;274:78-9. [CrossRef]

22. Petrache I, Otterbein LE, Alam J, Wiegand GW, Choi AM. Heme oxygenase-1 inhibits TNF-alpha-induced apoptosis in cultured fibroblasts. Am J Physiol Lung Cell Mol Physiol 2000;278:L312-9. [CrossRef]

23. Sen O, Caner H, Aydin MV, Ozen O, Atalay B, Altinors N, et al. The effect of mexiletine on the level of lipid peroxidation and apoptosis of endothelium following experimental subarachnoid hemorrhage. Neurol Res 2006;28:859-63. [CrossRef]

24. Singh S, Houng AK, Reed GL. Matrix Metalloproteinase-9 Mediates the Deleterious Effects of $\alpha 2$-Antiplasmin on Blood-Brain Barrier Breakdown and Ischemic Brain Injury in Experimental Stroke. Neuroscience 2018;376:40-7. [CrossRef]

25. Dang B, Duan X, Wang Z, He W, Chen G. A Therapeutic Target of Cerebral Hemorrhagic Stroke: Matrix Metalloproteinase- 9. Curr Drug Targets 2017;18:1358-66. [CrossRef]

26. Lin CC, Tseng HW, Hsieh HL, Lee CW, Wu CY, Cheng CY, et al. Tumor necrosis factor-alpha induces MMP-9 expression via $\mathrm{p} 42 / \mathrm{p} 44$ MAPK, JNK, and nuclear factor-kappaB in A549 cells. Toxicol Appl Pharmacol 2008;229:386-98. [CrossRef]

27. Buommino E, De Filippis A, Gaudiello F, Balato A, Balato N, Tufano MA, et al. Modification of osteopontin and MMP-9 levels in patients with psoriasis on anti-TNF- $\alpha$ therapy. Arch Dermatol Res 2012;304:481-5.

28. Chen SD, Wu CL, Hwang WC, Yang DI. More Insight into BDNF against Neurodegeneration: Anti-Apoptosis, Anti-Oxidation, and Suppression of Autophagy. Int J Mol Sci 2017;18:545. [CrossRef] 
DENEYSEL ÇALIŞMA - ÖZET

\section{Adalimumab’ın tavşanlarda deneysel subaraknoid kanama sonrası oluşan serebral vazospasm üzerine iyileştirici etkileri \\ Dr. Gökhan Toğuşlu, ${ }^{1}$ Dr. Mehmet Fatih Erdi, ${ }^{2}$ Dr. Densel Araç, ${ }^{2}$ Dr. Fatih Keskin, ${ }^{2}$ Dr. İbrahim Kılınç, ${ }^{3}$ Dr. Gökhan Cüce ${ }^{4}$}

${ }^{1}$ Kadirli Devlet Hastanesi, Beyin Cerrahisi Kliniği, Osmaniye

${ }^{2}$ Necmmetin Erbakan Üniversitesi Meram Tıp Fakültesi, Nöroşirurji Anabilim Dalı, Konya

${ }^{3}$ Necmmetin Erbakan Üniversitesi Meram Tıp Fakültesi, Tıbbi Biokimya Anabilim Dalı, Konya

${ }^{4}$ Necmmetin Erbakan Üniversitesi Meram Tıp Fakültesi, Histoloji ve Embriyoloji Anabilim Dalı, Konya

AMAÇ: Tümör nekroz faktörü $\alpha$ (TNF $\alpha$ ) için yeni nesil bir rekombinant insan monoklonal antikoru olan adalimumab (ADA), güçlü anti-enflamatuvar etkilere sahiptir. Serebral vazospazmın gelişimi ve ilerlemesi için artmış enflamasyonun rolü detaylı bir şekilde belirlenmiştir. Bu çalışmada, tavşanlarda deneysel olarak oluşturulan serebral vazospazm modelinde ADA'nın biyokimyasal ve histopatolojik yöntemlerle muhtemel hafifletici ve nöroprotektif etkileri araştıııldı.

GEREÇ VE YÖNTEM: Otuz adet erkek Yeni Zelanda beyaz tavşanı rastgele kontrol, sadece subaraknoid kanama (SAH) ve SAH artı ADA tedavi gruplarına ayrıldı. SAH, tek sisterna magna otolog arteriyel kan enjeksiyonu ile oluşturuldu. ADA tedavisine intrasisternal kan enjeksiyonundan hemen sonra başlandı ve günde 72 saat devam edildi. Araştırmalar için elde edilen SAH, serum ve beyin sapı dokusunun uyarılmasından 72 saat sonra hayvanlar öldürüldü. SAK oluşumundan 72 saat sonra araştırma için serum ve beyin sapı doku örnekleri alındıktan sonra hayvanlar sakrifiye edildi. BULGULAR: Beyin sapı dokusu ve plazma TNF $\alpha$ ve interlökin- I $\beta$, beyin sapı dokusu matriks metaloproteinaz-9 seviyeleri SAH sonrasında arttı ve tedaviden sonra kısmen azaldı. Beyin kaynaklı nörotrofik faktörün plazma seviyeleri SAH sonrasında azaldı ve tedaviden sonra kısmen restore edildi. ADA tedavisi, vazospastik baziler arterlerin orta kesit alanını önemli ölçüde arttırdı, baziler arter duvarı kalınlığını düşürdü ve ayrıca endotelyal apoptozisi düzeltti.

TARTIŞMA: Sonuçlar ADA'nın deneysel tavşan vazospazmında, serebral vazospazmı iyileştirmede etkili bir nöroprotektif ajan olduğunu göstermektedir.

Anahtar sözcükler: Adalimumab; enflamasyon; nöroproteksiyon; serebral vazospasm; subaraknoid kanama; sitokin; tavşan.

Ulus Travma Acil Cerrahi Derg 2020;26(6):847-852 doi: 10.14744/tjtes.2019.52504 